\title{
Türkiye Tarım Sigortası Sisteminde Görülen Sorunlar ve Alternatif Model Arayıșı
}

\section{Fatma Eymen YAZGI'IID, Emine OLHAN ${ }^{2}$}

\author{
I Tarım ve Orman Bakanlığı, AB ve Dıș ilișkiler Genel Müdürlüğü, Ankara \\ 2 Ankara Üniversitesi Ziraat Fakültesi, Tarım Ekonomisi Bölümü, Ankara
}

Öz: Tarım sektörünü tehdit eden risklerin teminat altına alınabilmesi amacıyla 2005 yılında 5363 sayılı Tarım Sigortaları Kanunu çıkartılmıștır. Bu kanunla bir sigorta havuzu olușturulmuș olup, tarım sigortası yaptıran üreticilerin desteklenmesi ve prim tutarının \%50'sinin (don teminatında \%66.7) devlet tarafından karșılanması hedeflenmiștir. Bu çalıșmanın temel amacı, Türkiye'de tarım sigortasının yaygınlaștırılmasına yönelik olarak politika önerileri geliștirmektedir. Bu kapsamda, Tekirdağ ili Hayrabolu, Malkara ve Süleymanpașa ilçeleri araștırma alanı olarak seçilmiștir. Tarım ve Orman Bakanlığı'ndan (TOB) temin edilen veriler ıșığında 16,77I ișletmeden olușan bir örnek çerçevesi olușturulmuștur. Oransal Örnek Hacmi formülü kullanılarak görüșülecek üretici sayısı belirlenmiștir. 192 üretici ile yapılan anketlerden elde edilen veriler kullanılarak tarım sigortası yaptıran üreticilerin karșısaștığı sorunlar ve sigorta yaptırmayan üreticilerin yaptırmama nedenleri frekans dağılım çizelgeleri ile çözümlenmiș, üreticilerin yenilikçi sigorta ürünlerine bakıșı skor testi ile ortaya konulmuștur. Yapılan analizler sonucunda araștırma bölgesindeki üreticilerin tarım sigortası sisteminde karșılaștıkları sorunlar eksperlerin yeterli bilgiye sahip olmaması, hasar tespitini doğru yapamamaları, kaba davranıșları ve sigorta maliyetlerinin yüksek olması olarak sıralanmaktadır. Sonuç olarak, gelir sigortası tarım sigortasının yaygınlaștırılması için hayata geçirilebilecek alternatif bir modeldir. Üreticiler tarafından ifade edilen eksper kaynaklı sorunların giderilmesi, sistemin ișleyișine yönelik bazı konuların açıklığa kavușturulması ve sigorta prim miktarının aktüeryal çalıșmalar esas alınarak üreticilerin beklentilerini karșılayacak șekilde hesaplanması tarım sigortası yaptıran üretici sayısını artıracak unsurların bașında yer almaktadır. Sigorta primlerine verilen devlet desteğinin en az $\% 50$ olacak șekilde devam ettirilmesi ve hatta devlet kaynakları uygunsa devlet desteğinin artırıması sigortalı olma oranını artıracaktır.

Anahtar Kelimeler: tarım sigortası, yenilikçi tarım sigortası sistemleri, Tekirdağ ili

\section{Problems in Agricultural Insurance System in Turkey and Seeking Alternative}

\begin{abstract}
The Agricultural Insurance Law (No. 5363) was enacted in 2005 to ensure the risks threatening the agriculture sector. An insurance pool has been established on the basis of this law which targets to support to producers who have agricultural insurance. The government subsidies $50 \%$ of the premium rate in general while $66.7 \%$ in frost risk. The main objective of the study is to develop policy recommendations for the extensification of agricultural insurance in Turkey. In this context, Hayrabolu, Malkara and Süleymanpașa districts of Tekirdağ province were selected as research areas. In the light of data obtained from the Ministry of Agriculture and Forestry, a sampling frame of 16,77I producers has been established. The Proportional Sampling method was used to calculate the number of producers to be interviewed. The problems encountered by producers who have agricultural insurance and the reasons why non-insured producers have not, were analyzed with frequency distribution charts, and the vision of producers on innovative insurance products was revealed by scoring test through data obtained from the questionnaires conducted with 192 producers. Problems encountered in the agricultural insurance system are: lack of expert capacity with sufficient knowledge, inaccurate damage detection, rude behavior of the experts and high cost of insurance. In conclusion, income insurance is an alternative model for extensification of the agricultural insurance. The elimination of problems related to the experts expressed by the producers, clarification of some issues on the functioning of the insurance system and calculating the amount of insurance premiums in such a way as to meet the expectations of the producers based on actuarial studies are the main factors that will increase the number of producers having agricultural insurance. The state subsidy provided for insurance premiums should be maintained at minimum $50 \%$, and even more, if the state resources are available, increasing state support will increase the insurance rate.
\end{abstract}

Keywords: : agricultural insurance, innovative agricultural insurance schemes, Tekirdag province

GiRiș

Tarım sektörü, dünyada beslenme ihtiyacını karșılaması, istihdam yaratması ve sanayi sektörüne ham madde sağlayarak bu ürünlere talep yaratması nedeniyle ülke kalkınması açısından önemli bir sektördür ve genel ekonomi içinde önemli bir yere sahiptir. Tarım sektörü doğa șartlarına bağlı olarak üretim yapılması sebebiyle dünyanın her yerinde hassas ve stratejik bir sektör olarak ele alınmaktadır.

Ulusal ve uluslararası araștırma kurumlarının tahminlerine göre Türkiye, iklim değișikliğine en duyarlı bölgelerden birinde yer almaktadır. Bu nedenle, iklim değișikliği etkilerinin tarımsal üretimde doğal afet risklerini artırması beklenmektedir (Anonim, 2007a; Anonim, 2007b; Dellal, 2012). Gelișmiș ülkeler uyguladıkları Tarımda Risk Yönetim Programları ile tarımsal üretimi tehdit eden doğal risklerin olușturduğu verim ve gelir kayıplarını çiftçinin üzerinden alıp, sigorta sistemlerine

Sorumlu Yazar: eymen.toprak@tarim.gov.tr Bu çalșma doktora tezi ürünüdür.

Geliș Tarihi: 2 Ekim 2017

Kabul Tarihi: 31 Mayıs 2018 
transfer etmektedirler. Tarım sigortası, tarımsal üretim sürecinde her türlü doğal risk, hastalık ve kazalar sonucunda bitkisel ve hayvansal ürünler ile tarımsal varlıklarda olușabilecek zarar ve kayıpların teminat altına alınması ve böylece sigortalının varlığının devamlılığının sağlanması șeklinde ifade edilmektedir. $\mathrm{Bu}$ sistem sayesinde kișiler, karșı karșıya bulundukları tehlikelerin neden olabileceği parayla ölçülebilen zararlarını küçük miktarlarda ödedikleri primler karșılığında teminat altına almaktadırlar (Dinler, 2000; Demir, 2003; Çetin, 2007; Çukur ve ark., 2008; Anonim 2013).

Gelișmiș ülkelerde sigortalanan tarım alanlarının toplam tarım alanları içerisindeki payının \%25-90 arasında değiștiği görülmektedir (Mahul and Stutley, 2010a; Mahul and Stutley, 20l0b). Türkiye'de tarım sigortalarının uygulandığı 1957 yılından 2006 yılına kadar olan dönemde bitkisel üretim alanında sigortalı tarım alanlarının toplam tarım alanları içerisindeki payının oldukça düșük olduğu (\%0.5 dolaylarında), ancak devlet destekli 5363 Sayılı Tarım Sigortaları Kanunu (2। 06.2005 tarihli 25852 sayılı Resmi Gazete) çerçevesinde Çiftçi Kayıt Sistemi (ÇKS)'ne kayıtlı tarım alanlarında bu oranın \%।6.l'e yükseldiği görülmektedir (TOB, 20I5a). Söz konusu artıș tarım sigortası sistemi bulunan diğer ülkelerle kıyaslandığında oldukça düșük kalmaktadır.

Yapılan literatür incelemelerinde, Türkiye'deki mevcut sistemi tanıtıcı ve üretici algılarını ölçen çalıșmalara sıkça rastlanılmıștır. Bu çalıșma farklı sigorta uygulamalarının incelenmesi, Türkiye'de uygulanan mevcut tarım sigortası politikalarının değerlendirilmesi, tarım sigortası yaptırılmama nedenleri ve tarım sigortalarının yaygınlaștırılması için yeni politika yaklașımlarını ortaya koyması açısından önemlidir.

Bu çalıșmada, üreticilerin mevcut sigorta sistemine ilișkin gördükleri sorunların ortaya konulması, tarım sigortalarının yaygınlaștırılması için mevcut sorunların çözümüne yönelik olarak politika önerilerinde bulunulması ve üreticilerin yenilikçi sigorta ürünlerine olan bakıșının ortaya konulması amaçlanmıștır.

Tarım sigortası prim ve poliçe üretiminin branș bazında \%75'ini bitkisel üretim sigortası olușturmakta ve 20072013 yılları arasında TARSIM (Tarım Sigortaları Havuzu) faaliyet raporlarında yer alan bitkisel ürün sigortalarında il bazında poliçe sayısı sınıflamasına göre en yüksek poliçe sayısı Tekirdağ ilinde görülmektedir. Bu nedenle çalıșma kapsamındaki anket çalıșması 2015 yılı üretim döneminde Tekirdağ ilinin Hayrabolu, Malkara ve Süleymanpașa ilçelerinde bitkisel ürün sigortası yaptıran üreticilerle gerçekleștirilmiștir. Söz konusu yıllar arasında Türkiye çapında yapılan bitkisel ürün sigortalarında Tekirdağ ili ortalama \% II'lik bir oranla birinci sırada yer almıștır (TARSiM, 20I3). Belirlenen üç ilçedeki toplam üretici sayısı hem Tekirdağ'daki üretici sayısının \%62.08'ini hem de Tekirdağ'daki sigorta yaptıran üretici sayısının \%6I.4'ünü olușturmaktadır (TOB, 20I5b; TARSiM, 2015).

\section{MATERYAL ve YÖNTEM}

Materyal

Çalıșmanın materyalini 2015 yılı üretim döneminde Tekirdağ ilinin Hayrabolu, Malkara ve Süleymanpașa ilçelerinde bitkisel ürün sigortası yaptıran 192 üreticiyle gerçekleștirilen anket çalıșması olușturmaktadır. Çeșitli kurum ve kurulușların konu ile ilgili olan yayınları, konuya ilișkin kitaplar, makaleler ve resmi kurumlar (TOB, TARSIM) ile uluslararası kurulușların (Birleșmiș Milletler Kurulușları, vb.) resmi internet sayfaları çalıșma sırasında kullanılan ikincil verilerdir.

\section{Örnek ișletmelerin Seçimi}

Araștırmada anket uygulanacak üreticilerin tespiti için Tarım ve Orman Bakanlığı (TOB) ve TARSiM yetkilileri ile görüșmeler yapılarak, bu kurulușların resmi kayıtlardan faydalanılmıștır. TOB'ndan temin edilen ÇKS kayıtları incelenerek Tekirdağ iline ait Hayrabolu, Malkara ve Süleymanpașa ilçelerinde ÇKS'ye kayıtlı 16,77I ișletmeden olușan bir örnek çerçevesi olușturulmuștur.

Örnek hacminin belirlenmesinde, Oransal Örnek Hacmi formülü kullanılmıștır (Newbold, 1995).

Formülde;

$$
n=\frac{N p(1-p)}{(N-1) \sigma_{\hat{p}_{x}}^{2}+p(1-p)}
$$

$\mathrm{n}=$ Örnek hacmi,

$\mathrm{N}=$ Araștırma kapsamına giren ilçelerdeki ișletme sayısı (üretici sayısı),

$\sigma^{2}=$ Varyans,

$\mathrm{p}^{p_{x}}$ ve $\mathrm{q}=$ tarım sigortası yaptıran ve yaptırmayan üreticilerin oranını ifade etmektedir. Araștırma çerçevesinde 3 ilçede sigortalı oranı $p=0.45$ değeri kabul edilmiș, $N=16,77 \mid$ olarak alınıp, \%95 güven aralığı ve \%7 hata payı için örnek hacmi 192 olarak bulunmuștur.

\section{Yöntem}

Tarım sigortası yaptıran üreticilerin mevcut sistemde gördükleri sorunları, tarım sigortası yaptırmayan üreticilerin ise sigorta yaptırmama nedenlerini ortaya koymak amacıyla sahadan elde edilen verilerin yorumlanmasında frekans dağılım çizelgelerinden faydalanılmıștır. Üreticilerin yenilikçi sigorta ürünleri arasındaki tercihlerini ortaya koymak, karșılaștırma yapmak ve önem derecelerini belirlemek amacıyla skor testinden faydalanılarak elde edilen veriler yorumlanmıștır. Önem derecelerini belirlemek amacıyla 
değișkenlere ağırlık verilmiș olup, bunlar ilgili değișkenlerin yüzdeleri ile çarpılarak skorları elde edilmiș ve önem sıraları belirlenmiștir (Yurtlu ve ark., 2012). Burada üreticilerin vermiș olduğu cevaplar yeniliğe açık olmamaları (yenilikçi tarım sigortasını yaptırmayı düșünmemeleri), yeniliğe kısmen açık olmaları (yenilikçi tarım sigortasının maliyetine bağlı olarak karar vermeleri) ve yeniliğe açı olmaları (yenilikçi tarım sigortası yaptırmayı düșünmeleri) șeklinde 3 kategoride ele alınmıș ve bu kategorilerin ağırlıkları sırasıyla 0 , I ve 2 olarak tanımlanmıștır. Araștırma sonuçlarının değerlendirilmesi, yorumlanması ve sentezlenmesinde ikincil verilerden faydalanılmıștır.

\section{BULGULAR ve TARTIȘMA \\ Üreticilerin Özellikleri}

Araștırma bölgesindeki üreticilerden en genci 2I, en yașlısı 84 yașında olup, yaș ortalaması 50.9 olarak hesaplanmıștır. Sigorta yaptıran üreticilerin yaș ortalaması 50.4 ve yaptırmayan üreticilerin yaș ortalaması $5 \mathrm{I} .4$ olarak tespit edilmiștir.

Tarım sigortası yaptıran üreticilerin \%67'si lise öncesi, $\% 25$ 'i lise ve \%8'i üniversite mezunudur. Tarım sigortası yaptırmayan üreticilerde ise bu değerler sırasıyla \%6I, \%26 ve \%।3'tür. Araștırma bölgesinde tarım sigortası yaptıran üreticilerin ortalama deneyimlerinin 32 yıl, tarım sigortası yaptırmayan üreticilerin ise 30 yıllık bir tarımsal tecrübeye sahip oldukları görülmektedir.

Tarım sigortası yaptıran üreticiler (427.3 da), tarım sigortası yaptırmayan üreticilere (194.7 da) göre daha geniș ișletmelerde tarımsal faaliyetlerini sürdürmekte ve tarımsal faaliyetlerinin toplam gelirlerine olan katkısının daha fazla olduğu tespit edilmiștir.

Tarım sigortası yaptıran üreticilerin kırsal örgütlenmede daha fazla rol aldıkları, kooperatif/üretici birliği/dernek üyeliklerinin bulunduğu ve bunların içinde Tarım Kredi Kooperatifleri'nin öne çıktığı görülmektedir.

Benzer șekilde, tarım sigortası yaptıran üreticilerin kredi kullanım potansiyellerinin yüksek olduğu ve özellikle Türkiye Cumhuriyeti Ziraat Bankası'ndan kredi temin ettikleri tespit edilmiștir.

\section{Türkiye Tarım Sigortası Sisteminde Görülen Sorunlar}

Anket çalıșmasının gerçekleștirildiği yıl tarım sigortası yaptıran üreticilerin tarım sigortasına ilișkin mevcut düzen içerisinde gördükleri sorunlar eksperlerin özellikleri (hasar tespiti konusunda yeterli bilgiye sahip olmamaları, doğru hasar tespitinde bulunmamaları, üreticilere kaba yaklașımları), muafiyet oranlarının yüksek bulunması, sigorta prim miktarlarının yüksek bulunması, tarım sigortalarına verilen desteklerin az bulunması, hasar tespitinin zamanında yapılmaması, sigorta kapsamının genișletilmesi ve özel sigortacılık sistemine geri dönülmesi olarak sınıflandırılmıștır. Üreticilerin \% I7.2'si sorunlara ilișkin olarak fikir beyan etmezken, \%8'si mevcut düzenden memnun olduklarını ifade etmișlerdir (Çizelge I).

Çizelge I'de görüleceği üzere, üreticilerin mevcut düzende gördükleri en önemli sorun \%37.9 oranla

Çizelge I Tarım sigortası yaptıran üreticilerin mevcut düzene ilișkin sorunları

\begin{tabular}{lll}
\hline Sorunlar & Sayı & \%* \\
\hline Eksper (yeterli bilgiye sahip olma, doğru tespit, davranıs biçimleri) & 33 & 37.9 \\
Muafiyet oranı yüksek & 17 & 19.5 \\
Fikir beyan etmemiș & 15 & 17.2 \\
Prim miktarı yüksek & 12 & 13.8 \\
Mevcut sistemden memnun & 7 & 8.0 \\
Özel sigorta sistemine geri dönmek istiyor & 6.9 \\
Destek oranı az & 6 & 6.9 \\
Verim değerinin belirlenmesi noktasında üretici dikkate alınmıyor & 4.6 \\
Sigorta kapsamı dar & 4 & 4.6 \\
Hasar tespitinin zamanında yapılmaması & 4.6 \\
Diğer & 4.5 \\
\hline
\end{tabular}

*Üreticiler birden fazla cevap verdiği için toplam değer \%I00'ü geçmektedir.

eksperlerin bireysel özellikleriyle ilișkilidir. Üreticiler, eksperlerin sigortaya konu olan unsurlara ilișkin bilgi düzeylerinin yetersiz olması nedeniyle doğru değerlendirmelerde bulunamamalarından șikayet etmișlerdir. Buna ek olarak, üreticiler eksperlerin TARSiM'e bağlı olmaları nedeniyle yanlı bir tutum sergilediklerini ve hasar oranlarını daha düșük gösterdiklerini düșünmektedirler. Üreticiler, eksperlerin ayrıca kendilerini bilgilendirmemeleri ve kaba davranıșlarından rahatsız olduklarını ifade etmișlerdir.
Üreticilerin ifade ettikleri ikinci önemli sorun \%19.5 oranla muafiyet oranının yüksek olmasıdır (Çizelge I). Muafiyet oranı, daha önceden belirlenen ve poliçede de ișlenen, önceden belirlenmiș bir miktar (TL) veya orana (yüzde) kadar olan hasarların sigortacı tarafından ödenmemesidir. Sigortalı bu miktar veya oranı așan hasarlara tazminat ödemektedir. Muafiyet oranları bitkisel ürünlerde farklılık göstermekle beraber, küçük çapta üretim yapan üreticilerin gelirlerinde dalgalanmaya sebebiyet vermektedir. 
Bir diğer sorun ise prim miktarlarının yüksek olmasıdır (Çizelge I). Üreticilerin bu konu ile ilgili olarak yaptıkları eleștirilerin bașında devlet destekli tarım sigortası sisteminin gelmesiyle birlikte prim miktarlarında yapılan artıșlardır. Buna ek olarak üreticiler prim miktarlarındaki bu artıș sebebiyle tarım sigortası primlerine verilen devlet desteğini de az bulmaktadırlar. Üreticilerin \%6.9'u devlet desteğinin artması gerektiğini düșünmektedir.

Tarım sigortası yaptıran üreticilerin üzerinde durdukları bir diğer önemli sorun ise özel sigorta sisteminden devlet destekli tarım sigortası sistemine geçișle birlikte sigorta hizmeti alınan șirketlerin hizmet kalitelerinin düștüğü ve tek fiyat politikasına geçildiği yönündedir. Üreticilerin \%6.9'u rekabetçi ortamın eksikliğini vurgulamakta ve özel sigortacllık sistemine geri dönmek istediklerini ifade etmektedirler. Bu üreticiler özel sigortacılık sisteminin rekabetçi ortam yaratması nedeniyle hem üreticilerin hem de sigorta șirketlerinin kazanacağını düșünmektedirler (Çizelge I).

Sigorta poliçelerindeki verim ve fiyat değerlerinin belirlenmesinde üreticilerin dikkate alınmaması, hasar tespitinin zamanında yapılmaması ve sigorta kapsamının dar olması (kapsama hastalıkların da eklenmesi) tarım sigortası yaptıran üreticilerin ifade ettikleri diğer sorunlardır (Çizelge I).

\section{Üreticilerin Tarım Sigortası Yaptırmama Nedenleri}

Daha önceki yıllarda tarım sigortası yaptırıp 2015 üretim döneminde tarım sigortası yaptırmayan üreticilerin tarım sigortası yaptırmama nedenleri incelendiğinde; zararlarının daha önce karșilanmaması, üreticilerin prim miktarlarını yüksek bulmaları, tarımsal faaliyet alanında risk görmemeleri, çevrelerinde tarım sigortasından mağdur olan kișilerin varlığı (komșu/akraba tecrübesi) nedenlerine bağlı olarak sigorta yaptırmadıkları görülmektedir.

Çizelge 2'de görüleceği üzere, Türkiye'de tarım sigortacılığının uygulanmaya bașladığı dönemlerden itibaren sigorta yaptırmayı tercih etmeyen üreticilerin oranı $\% 60$ 'tır. $\mathrm{Bu}$ üreticiler sigorta yaptırmama nedenlerini yetiștiricilik alanlarında risk görmemeleri, arazilerinin küçük olması, prim miktarlarını yüksek bulmaları, hasarların karșılanmadığını ve inançlarına ters olması olarak ifade etmișlerdir.

Sigorta yaptırmayan 105 üreticinin 42'si yani \%40'ı daha önce sigorta yaptırmış ve sonrasında bazı nedenlerle sigorta yaptırmaktan vazgeçmiștir. Daha önceki yıllarda tarım sigortası yaptırıp 2015 üretim döneminde tarım sigortası yaptırmayan üreticilerin tarım sigortası yaptırmama nedenlerinin bașında hasarlarının muafiyet oranı altında kalması ve eksperin yanlıs değerlendirme yapması nedenleriyle zararlarının karșılanmaması (\%40.5) ve sigorta primlerini yüksek bulmaları (\%26.2) gelmektedir. Bunu yetiștiricilik alanlarında risk görmemeleri nedeniyle sigorta yaptırmayan üreticiler (\%16.7) ile sosyal çevrelerinde yașanan olumsuz tecrübelerden dolayı tarım sigortasına temkinli yaklașan üreticiler izlemektedir (Çizelge 2).

Çizelge 2 Tarım sigortası yaptırmayan üreticilerin yaptırmama nedenleri

\begin{tabular}{llll}
\hline Sorunlar & & Sayı & $\%$ \\
\hline & Zararın daha önce karșlanmaması & 17 & 40.5 \\
& Primler yüksek & 11 & 26.2 \\
Daha önce sigorta & Risk görmemesi & 7 & 16.7 \\
yaptırdı & Komșu/akraba olumsuz tecrübeleri & 4 & 9.5 \\
& Diğer nedenler & 3 & 7.1 \\
& Toplam & 42 & $40.0^{*}$ \\
Hiç sigorta yaptırmadı & & 63 & 60.0 \\
Genel Toplam & & 105 & 100.0 \\
\hline
\end{tabular}

* Daha önceki yıllarda tarım sigortası yaptırıp 2015 üretim döneminde tarım sigortası yaptırmayan üreticiler genel toplamın \%40'ını olușturmakta olup, bu değer tabloda \% I00'e endekslenerek ifade edilmiștir.

Üreticilerin Yenilikçi Sigorta Ürünlerine Olan sistemdir (Śkees ve Reed, 1986). Bölgesel verim sigortası Bakıșı sözleșmeleri ise belirli bir bölgedeki ortalama verimin

Literatürde yenilikçi sigorta ürünleri; gelir sigortası, bireysel ve bölgesel verim sigortası, indeks sigortalar ve tüm çiftlik sigortaları olmak üzere beș gruba ayrılmaktadır. Gelir sigortası, verim, fiyat veya her ikisinde meydana gelen düșüșlere ek olarak sigorta dönemi boyunca pazardaki fiyat değișikliği sonucunda üreticinin gelirini korumayı amaçlamaktadır (Kang, 2007). Bireysel verim sigortaları, bireysel ortalama verimin önceden belirlenmiș bir düzeyin altına düșmesi durumunda tazminat ödemesi yapılmasına dayanan bir 42 önceden belirlenmiș bir düzeyin altına düșmesi durumunda ödemede bulunmayı taahhüt etmektedir (Wenner ve Arias, 2003). Bu bölgeler genellikle ilçe düzeyinde, gizli anlașmaları engelleyecek büyüklükle ve bireysel üreticilerin fiziksel ve piyasa koșullarını temsil etmesini engellemeyecek küçüklükte olmaktadır (Kang, 2007).

Indeks esaslı sigorta ürünleri, üreticiler tarafından yapılan fiili zararlar yerine hava değișkenlerine (yağıș, sıcaklık, rüzgâr hızı vs.), belirli bir bölgenin verimine, fiyatlara ve 
hayvancılıkta ölüm oranlarına ilișkin belirlenmiș olan indekslerdeki değișikliklere göre tazminat ödemesi yapmaktadır. Indeks sigorta ürünleri çiftlik düzeyinde tarihsel ya da gerçek verim verilerini gerektirmemektedir (Anonim, 20ll).

Tüm çiftlik sigortası; diğer sigorta programlarının aksine, ürün bazlı bir yaklașım yerine çiftlik bünyesinde bulunan tüm ürünleri kapsamına alan bir programdır. Tüm çiftlik sigortasının temelinde bir üründe meydana gelen verim/gelir kaybına karșı bir tazminat ödemesinin yapılması için çiftlik genelindeki üretimin tetikleyici değerin altına düșmesi gerekliliği yatmaktadır (Bielza ve ark., 2007).
Üreticilerin yenilikçi sigorta ürünleri hakkında bilgileri araștırıldığında, üreticilerin \%90'ına yakın bir kısmının söz konusu programları bilmediği tespit edilmiș, bu nedenle anket çalıșması esnasında bilgilendirme yapılmıștır. Çizelge 3'ten görüleceği üzere skor hesabına göre üreticilerin ilk olarak tercih ettikleri yenilikçi sigorta ürününün bireysel verimi esas alan verim sigortası olduğu görülmektedir. Bunu hava durumu indeks sigortası, gelir sigortası, bölgesel verimi esas alan verim sigortası ve tüm çiftlik sigortası izlemektedir.

Üreticilerin verim sigortasına ilișkin olarak bireysel verime dayalı sigorta sisteminin tercih etme oranı \%66.I ile ilk sırada yer almaktadır (Çizelge 3). Üreticiler için

Çizelge 3 Üretici gözüyle yenilikçi sigorta ürünlerinin değerlendirilmesi (skor) Yenilikçi Sigorta Úrünleri

\begin{tabular}{lllllll}
\hline $\begin{array}{l}\text { Önem Derecesi } \\
\text { (Ağırık olarak) }\end{array}$ & $\begin{array}{l}\text { Gelir } \\
\text { sigortası }\end{array}$ & $\begin{array}{l}\text { Tüm çiftlik } \\
\text { sigortası }\end{array}$ & $\begin{array}{l}\text { Verim } \\
\text { sigortası } \\
\text { (bireysel) }\end{array}$ & $\begin{array}{l}\text { Verim sigortası } \\
\text { (bölgesel) }\end{array}$ & $\begin{array}{l}\text { Hava durumu } \\
\text { indeks sigortası }\end{array}$ \\
\hline Yeniliğe açık & Sayı (adet) & 73 & 100 & 62 & 90 & 70 \\
değil (0) & Oran (\%) & 38.0 & 52.1 & 32.3 & 46.9 & 36.5 \\
Kısmen yeniliğe & Sayı (adet) & 7.0 & 15 & 3.0 & 1.0 & 3.0 \\
açık (I) & Oran (\%) & 3.6 & 7.8 & 1.6 & 0.5 & 1.6 \\
Yeniliğe açık (2) & Sayı (adet) & 112 & 77 & 127 & 101 & 119 \\
& Oran (\%) & 58.3 & 40.1 & 66.1 & 52.6 & 61.9 \\
TOPLAM & Toplam skor* & 120.2 & 88 & 133.8 & 105.7 & 125.4 \\
& Önem sırası & 3 & 5 & 1 & 4 & 2 \\
& Sayı (adet) & 192 & 192 & 192 & 192 & 100 \\
\hline
\end{tabular}

*Skor:Ağırlık x Oran olarak hesaplanmıștır.

bireysel verim geçmișlerinin esas alınması sistemi cazip kılmaktadır. Bölgesel verim sigortasının bireysel verim sigortasına göre daha düșük bir oranda tercih edilmiș olmasının nedeni (\%52.6), bölge genelinde verim kaybı olmaması durumunda hasar gören üreticinin de tazminat alamamasıdır. Ancak bireysel verim sigortalarının ahlaki istismar ve ters seçim risklerine açık olması nedeniyle risk yükleniciler (devlet ve/veya özel sektör) taahhüt edilen zararların karșılanması noktasında kendilerini korumak için sigorta prim fiyatlarını artırmaktadır ve bu prim fiyatları bazı durumlarda ödenmesi muhtemel olan tazminat tutarlarını așmaktadır dolayısıyla sözü edilen sigorta programının pratikte uygulanabilirliği azalmaktadır.

Üreticilerin hava durumu indeks sigortasına olan bakıș açıları değerlendirildiğinde \%62'sine yakınının sigorta yaptırma eğiliminde olduğu görülmektedir. Hava durumu indeks sigortanın maliyeti konusuna vurgu yapan üreticilerin düșük oranda (\%।.6) olduğu görülmektedir (Çizelge 3). Üreticilerin bu sigortayı seçmelerindeki en önemli etken eksperler tarafından bir değerlendirme ve hasar tespiti yapılmamasıdır. Hava durumu indeks sigortaları genellikle tarımsal veri sıkıntısı olan gelișmemiș ülkeler için tavsiye edilmektedir. Tarım sigortası alanında gelișmiș ülkelerde ise bu sigorta sistemleri çok kısıtlı alanlarda kullanılmaktadır. Sigorta sisteminin en büyük avantajı basit meteorolojik verileri veya indeks değerleri kullanarak eksperlerden bağımsız bir șekilde hasar tespitinde bulunabilmesi olarak değerlendirilse de, üreticilerin üretim süresi boyunca verimini artıracak uygulamaları göz ardı etmesi, indeks değerlerin hesaplanmasındaki karmașıklık, bölgesel uygulamalarda daha bașarılı sonuçlar vermesi ve indeks değerlerin sigorta șirketinin lehine göre hesaplanması riskinin oldukça yüksek olması nedeniyle tarımsal veri altyapısı yetersiz olan/geliștirilen ülkelerde tercih edilmektedir. Bu sigorta sisteminin üreticiler tarafından tercih edilmesinin temel nedeni üreticilerin eksperler ile sorunlar yașıyor olmasıdır.

Üreticilerin \%58.3'ü verim, fiyat veya her ikisinde meydana gelen düșüșlerin neden olduğu gelir kayıplarını telafi etmeyi amaçlayan gelir sigortasını tercih edebileceğini, \%3.6'sı prim maliyetlerinin yüksek olabileceğini dolayısıyla kararsız kaldıklarını ifade etmiștir (Çizelge 3). Üreticilerin gelir sigortasını seçme nedenlerinin bașında garantilenen verimin üreticinin daha önceki verim ortalamasına göre belirlenmesi ve garantilenen fiyatın, ürünün hasat zamanındaki pazar fiyatına göre veya taban fiyattan belirlenmesi gelmektedir. Üreticilerin \%38'i, tazminat tutarlarının hasat zamanındaki pazar fiyatı esas alınarak belirlenmesi durumunda tazminat bedellerini geç alacakları çekincesiyle bu sigorta ürünü tercih etmemiștir (Çizelge 3).

Üreticilerin 4. tercihi olan bölgesel verim sigortasında tazminatların bireysel verim ortalamalarından bağımsız bir șekilde hesaplanması bu sigortanın en büyük avantajını 
olușturmaktadır. Bu sistem, üreticilerin risk görülmesi durumunda daha fazla tazminat alabilmeleri için bireysel verim ortalamalarını ilçe ortalamasının üzerine çıkarmaları konusunda teșvik etmektedir.

Günümüzde gitgide yaygınlașan tüm çiftlik sigortasını tercih etme oranı \%40.I ile son sırada yer almaktadır. Tüm çiftlik sigortası üretime konu olan materyal, aletekipman ve binaların yanı sıra çalıșan kișileri sigorta kapsamına almaktadır. Üreticilerin \%7.8'i maliyetinin yüksek olacağı düșüncesiyle bu sigorta ürününü tercih etme noktasında kararsız kalmıș ve prim miktarlarının makul olması koșuluyla bu tip bir sigortayı tercih edebileceklerini vurgulamıșlardır (Çizelge 3). Üreticilerin $\% 52$.l'i, sigorta prim miktarlarının yüksek olması ve tazminat ödemesinin çiftlik genelindeki zararın daha önceden belirlenen tetikleyici değerin altına düșmesi koșuluna bağlanması nedeniyle söz konusu sigorta ürününü tercih etmediklerini ifade etmișlerdir (Çizelge 3).

\section{SONUÇ}

Türkiye'de tarım sigortasının yaygınlaștırılmasına yönelik olarak politika önerileri geliștirmeyi amaçlayan bu çalıșma kapsamında eksperlerin doğru hasar tespitinde bulunamadığı yargısını kırmak için belirli bir ürün grubunda uzmanlașmıș eksper kadrolarının ivedilikle olușturulması gerekmektedir. Bunun için istihdam edilen eksperlerin temel eğitimlerini tamamlaması sonrasında çalıșma bölgelerinde yetiștirilen bitkisel ürünler ile ilgili olarak konusunda uzmanlașmıș kurumlar tarafından (TOB’a bağlı araștırma enstitüleri veya üniversiteler) ikinci bir eğitime tabi tutulması isabetli olacaktır. Buna ilaveten, üreticilerin eksperler tarafından yapılan değerlendirmeleri yanlıș/eksik bulmaları durumunda itiraz hakkına sahip oldukları konusunda bilgilendirilmeleri önem tașımaktadır. Bu konuda gerekli bilgilendirme poliçe hazırlanması ve hasar ihbarı așamalarında özel sigorta șirketleri tarafından yapılabilir.

Üreticilerin sigorta programlarının kendilerini koruduklarına inanmaları ve program koșullarının adil ve güvenilir olduğunu hissetmeleri sigorta programlarının bașarılı olmasının önkoșuludur. Üreticilerin, eksperlerin objektif değerlendirmelerde bulunamadıklarını ifade etmeleri ve eksperlerin bağımsızlığı ile ilgili șüphe duymaları sistemin güvenirliliğini tehlike altına atmaktadır. $\mathrm{Bu}$ nedenle, TARSIM tarafından üreticilere eksperlerin konumu ve görevlendirilme süreçleri ile ilgili bilgilendirme yapılması ve bu yanlış algının bertaraf edilmesi oldukça önem arz etmektedir.

Eksperlerin üreticilere olan kaba davranıșları da eksper kaynaklı önemli bir sorun olarak ortaya çıkmaktadır. Eksperlere verilen temel eğitim programına iletișim teknikleri konusunun dahil edilmesi üretici-eksper arasındaki ilișkiyi güçlendirecektir.

Üreticilerin sigorta maliyetiyle ilișkili sorunlarının bașında muafiyet oranlarının ve prim bedellerinin yüksek bulunması gelmektedir. Prim miktarı, prim desteği ve muafiyet oranların devlet imkanları çerçevesinde, aktüeryal çalıșmalar esas alınarak üreticinin beklentilerine de hitap edecek șekilde hesaplanması sisteme katılımı arttıracağı gibi sistemin sürdürülebilirliğini de güvence altına alacaktır. Buna ek olarak, sigorta primlerine verilen devlet desteğinin en az \%50 (kuraklık sigortasında \%60 ve don teminatında \%66.7) olacak șekilde devam ettirilmesi ve hatta devlet kaynakları uygunsa devlet desteğinin artırılması tarım sigortasını yaptırma kararlarını olumlu yönde etkileyecektir.

Bu çalıșma kapsamında yenilikçi sigorta ürünleri arasında bulunan gelir sigortasının alternatif bir model olarak öne çıktığı görülmektedir. Gelir sigortası verim, fiyat veya her ikisinde meydana gelen düșüșlerin üreticilerin gelirlerinde yarattığı dalgalanmaları azaltmayı hedeflemesi nedeniyle oldukça önemlidir. Gelir sigortası sisteminin kurulması așamasında risk bölgelerinin olușturulması ve sigortaya ilișkin prim ve tazminat tutarlarının doğru olușturulabilmesi için sağlıklı ve güvenilir bilgi sistemlerine ihtiyaç duyulmaktadır. TOB tarafından geliștirilen ve hâlihazırda kullanılmakta olan Tarım Bilgi Sistemi aracılığı ile gelir sigortası için bireysel ortalama verim geçmiși bilgilerinin en kısa zamanda olușturulmasının yanı sıra sigorta modelinin uygulanabilmesi için vadeli ișlem borsalarının kurulması, lisanslı depoculuğun geliștirilmesi ve bunlarla ilgili gerekli mevzuat değișikliklerinin yapılması için ilgili Bakanlıklar ve üst kurumların bir arada çalıșması gerekmektedir.

Sonuç olarak tarım sigortasının sadece bir risk yönetim aracı olarak değerlendirilmemesi, aksine tüm tarım politikalarının merkezinde ele alınması gereken bir konudur. Türkiye koșulları dikkate alındığında; araștırma çerçevesinde değinilen mevcut sistem aksaklıkların giderilmesi ve üretici gelirlerindeki dalgalanmaları telafi edecek gelir sigortasının da bir seçenek olarak üreticinin tercihine sunulması, Türkiye'de tarım sigortası yaptıran üretici sayısını artıracağı düșünülmektedir.

\section{KAYNAKLAR}

Anonim (2007a) Türkiye İklim Değișikliği Birinci Ulusal Bildirimi, Web Sitesi: http://www.mgm.gov.tr/FILES/iklim/ulusalbildirimtr.pd f. Erișim Tarihi: I0.12.2014

Anonim (2007b) IPCC 4.Değerlendirme Raporu, Web Sitesi:

http://www.ipcc.ch/publications_and_data/ar4/syr/en/ contents.html. Erișim Tarihi: 10.12.2014

Anonim (20II) Weather Index-Based Insurance in Agricultural Development A Technical Guide. Web Sitesi:

http://www.ifad.org/ruralfinance/pub/WII_tech_guide .pdf. Erișim Tarihi: I I.02.20I5.

Anonim (2013) Tarım Sigortalarının Gelecek 10 Yılı Çalıștayı Raporu. Web Sitesi: www.tarsim.org.tr. Erișim Tarihi: 0I.10.2014.

Bielza M, Stroblmair J, Gallego J, Conte C, Dittmann C (2007) Agricultural Risk Management in Europe. I0Ist EAAE Seminar 'Management of Climate Risks in Agriculture', Berlin, Germany, July 5-6, 2007. Web Sitesi: http://mars.jrc.ec.europa.eu/mars/Bulletins- 
Publications/Agricultural-Risk-Management-inEurope. Erișim Tarihi: 17.10.2014.

Çetin B (2007) Tarım Sigortaları. Nobel Yayın 256, Ankara.

Çukur F, Saner G, Çukur T, Uçar K (2008) Malatya Iilinde Kayısı Üreticilerinin Riskin Transferinde Tarım Sigortasına Bakıș Açılarının Değerlendirilmesi: Doğanșehir İlçesi Polatdere Köyü Örneği, Ege Üniversitesi Ziraat Fakültesi Dergisi, 45 (2), Izmir.

Dellal i (2012) Impacts of Climate Change on Agriculture and Food Security in Turkey, Ministry of Environment and Urbanization of Turkey, Turkey's Second National Communication Project, Ankara. Web Sitesi: http://www.tr.undp.org/content/dam/turkey/docs/pro jectdocuments/EnvSust/UNDP-TR-SNC-

Tarim\%20ve\%20Gida\%20Guvencesi.pdf. Erișim Tarihi: 10.12 .2014 .

Demir A (2003) Tarım Sigortası, Tarımsal Ekonomi Araștırma Enstitüsü, Sayı:4, Nüsha:2, Eylül. Web Sitesi:http://www.tepge.gov.tr/Dosyalar/Yayinlar/df86 b2db29a74a07a5ae3783f7ecl4bb.pdf. Erișim Tarihi: 01.10 .2014

Dinler T (2000) Tarımda Risk Yönetimi ve Türkiye'de Tarım Sigortaları Uygulamaları, TMMOB Ziraat Mühendisleri Odası V. Teknik Kongresi Bildiri Kitabı 2.Cilt: I I I7-I I26, Ankara.

Kang M.G (2007) Innovative Agricultural Insurance Products and Schemes. FAO: Agricultural Management, Marketing and Finance Occasional Paper 12. Web Sitesi: ftp://ftp.fao.org/. Erișim Tarihi:18.02.2015.

Mahul O. and Stutley, CJ (2010a) Government Support to Agricultural Insurance Challenges and Options for Developing Countries. The World Bank. Web Sitesi: https://openknowledge.worldbank.org/handle/I0986/ 2432. Erișim Tarihi: 0l.10.2014.
Mahul O. and Stutley CJ (20I0b) Government Support to Agricultural Insurance: Challenges and Options for Developing Countries. Annex E International Experiences with Agricultural Insurance: Findings From a World Bank Survey of 65 Countries. World Bank. Web Sitesi: http://documents.worldbank.org/curated/en/69809/4 68163160913/pdf/5388IOPUB0Gove I0IOfficialOUse 0Onlyl.pdf. Erișim Tarihi: I5.10.2014.

Newbold P (1995) Statistics for Business and Economics, Prentice-Hall International, New Jersey.

Skees J, and Reed, M (1986) Rate-Making for Farm-Level Crop Insurance: Implications for Adverse Selection. American Journal of Agricultural Economics 68:653659.

TARSiM (20I3) 2007-20I3 Yılları Arasında Yayımlanan Faaliyet Raporları. Erișim Adresi: https://web.tarsim.gov.tr Erișim Tarihi: 01.03.2013

TARSIM (2015) TARSiM 2008-2014 Tanzim Yilları Arasında Türkiye Geneli ì Bazında Çiftçi Sayısı Bilgisi. TARSIM A.Ș'den talep edilen rapor.

TOB, Tarım ve Orman Bakanlığı (20I5a) Tarım Reformu Genel Müdürlüğü, Tarımsal Desteklemeler Daire Bașkanlığı. Basılmamıș 07.10.2015 Ankara.

TOB, Tarım ve Orman Bakanlığı (20I5b) Tarım Reformu Genel Müdürlüğü, Tarım Sigortaları ve Doğal Afetler Daire Bașkanlığı. Mülakat. Basılmamıș 10.12.2015 Ankara.

Wenner N. and Arias D (2003) Agricultural Insurance in Latin America: Where are we? Presented at the International Conference: Paving the Way Forward for Rural Finance, 2-4 June, Washington, DC, USA.

Yurtlu Y.B., Demiryürek, K., Bozoğlu, M.ve Ceyhan, V (20I2) Çiftçilerin Tarım Makineleri Kullanımına ilișkin Risk Algıları. Ege Üniv. Ziraat Fak. Dergisi: 49 (I): 93IOI. 
